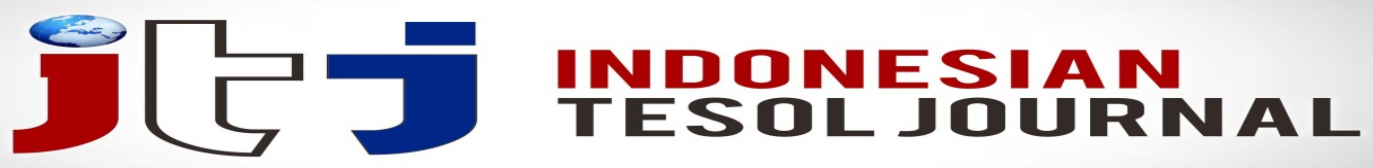

e-ISSN: 2622-5441(Online) Journal homepage: https://ejournal.iainpalopo.ac.id/index.php/ITJ/index

\title{
Integrating the deductive method and holistic assessment approach to teaching English grammar in English education programmes
}

\section{Made Sujana ${ }^{1}$, Ni Wayan Mira Susanti $^{1}$, Udin$^{1}$, and Arifuddin ${ }^{1}$ The University of Mataram, Indonesia}

Abstract: Mastery of English grammar for students in English education departments has a dual purpose, namely to improve their ability to communicate in English fluently and accurately, and to prepare them for becoming English teachers capable of explaining aspects of the English language. Thus, the English grammar course series is expected to equip students with the ability to use the language at the same time as explaining elements of the English language. This investigation aims to improve the learning, learning process, and the results of English grammar courses by integrating the deductive method and holistic assessment approach. This consists of assessment for learning (AfL), assessment as learning (AaL), and assessment of learning (AoL). The study was conducted among 72 fourth-semester students in the English education department at the University of Mataram. Data were collected using various techniques such as tests, observations, portfolios, and documentation, and were analysed qualitatively and quantitatively. From the analysis it was concluded that (1) the materials of EG were designed to fulfil the teaching and learning process by integrating the deductive method and the holistic assessment approach, with the proportion of AfL and AaL higher than that of AoL; (2) the integration produced a significant improvement in the TOEFL test (SWE section), with an increase of 63.24 points - from an average 388.84 on the pre-test to 452.01 on the post-test; (3) students responded positively to both the model used and the implementation of the deductive method and holistic assessment. The practical implication of this research is that those teaching grammar in English education need to consider applying holistic assessment in both design and implementation.

Keywords: assessment of, for, and as learning, deductive method, English grammar, holistic assessment

\section{INTRODUCTION}

Grammar incontestably plays an important role in teaching English as a foreign language. Mastery of grammar is an important means of achieving linguistic competence, as part of communicative competence, and of comprehending and creating spoken and written discourse in various communicative events (Huang, 2005). However, the heated debates among researchers and practitioners on EFL/ESL regarding the teaching of grammar arise not in relation to its importance, but are related more to what grammar knowledge learners should master - implicit or explicit - and how to teach it - inductively or deductively (Farahani, 2018; Krashen, 1999; Leachtenauer, 2004). Krashen (1985), for example, argues that 
grammar (and also vocabulary) is acquired naturally through the process of comprehending and responding to comprehensible input from reading or listening. However, this opinion is countered by other experts (for example Ellis, 2002; Hinkel \& Fotos, 2002; Leachtenauer, 2004). They all agree that grammar needs to be taught explicitly through formal instructions. Through formal instructions, learners can build awareness of grammar knowledge and notice grammatical elements that can be used for the preparation of language acquisition (Ellis, 1995). Without formal instruction, learners can never achieve a high level of competency in the target language (Leachtenauer, 2004). Furthermore, Larsen-Freeman (2001) argues that as an essential part of communication, grammatical competence is difficult to achieve just through exposure to natural input. However, up to now, the heated debates continue among experts and practitioners on the issue of explicit versus implicit instruction (Rahman \& Rashid, 2017; Alenezi, 2019; Althaqafi, 2018).

Starting from various arguments mentioned above, the present research is directed towards the application of explicit instruction in teaching English grammar for students at the EED in the University of Mataram. Following Celce-Murcia's (1992) suggestion that, in teaching formal grammar, it is necessary to consider such factors as learners' age, level of English, and the objectives of learning the language. Teaching English grammar to students at English education departments in most universities in Indonesia is directed towards at least three targets: (1) to be able to use grammar accurately for communication (spoken and written); (2) to be able to explain aspects of grammar, since they are preparing to become teachers; and (3) to fulfil graduation requirements, which commonly use TOEFL as a standard; in order to achieve the required scores in the TOEFL test, students must have high proficiency in grammatical points, especially in the structure and written expression (SWE) section. These targets imply that students are required to have both implicit and explicit knowledge of English grammar in order to achieve a range of learning goals. So far, various studies on English grammar for senior students at EED in the University of Mataram show that grammar mastery is still problematic. After learning EG for 6-8 credits, in addition to taking several other English subjects, many students still fail to achieve the expected grammar points, measured by TOEFL (SWE) (Arifuddin \& Sujana, 2004; Iswanto, 2016; Septiansyah, 2017). This finding has led to a reassessment of English grammar teaching at EED UNRAM.

Of the debates on explicit-implicit instructions raised above, the present study employs the deductive method for designing and teaching English grammar for students at EED UNRAM. It does so with the consideration that the students are prepared to achieve the three targets above, and that they are adult learners experienced in learning English. The deductive method is integrated with holistic assessment, consisting of assessment for learning (AfL), assessment as learning ( $\mathrm{AaL}$ ), and assessment of learning (AoL) to provide various forms of assessment of design and implementation. The research aims (1) to find models of teaching English grammar by integrating the deductive method and holistic assessment approach; (2) to describe students' achievement from the implementation of this integration; and (3) to find out students' opinions of teaching EG using this integration.

\section{Indonesian TESOL Journal}




\section{LITERATURE REVIEW}

\section{English grammar and its instruction}

The success of learning English as a foreign language is characterised by the ability of learners to use language to communicate in both spoken (listening and speaking) and written (reading and writing) English. However, according to Cahyono and Widiati (2011), the success of the communication above cannot be separated from the role of elements of language as 'language learning ingredients', which include grammar, vocabulary and the sounds of the language. Of the three linguistic elements, grammar is considered the foundation for the development of other language skills (Weissberg, 1974, in Cahyono \& Widiati, 2011).

In the grammar translation method (GTM) era, learning grammar was considered the most important part of language learning, since language at that time was defined as a set of rules. At that time, it was believed that learning a language primarily involved learning the rules of the language, and that communication skills would develop automatically after mastering grammar. However, this was not proven. Since then, the popularity of grammar learning began to fade, and the approach was even abandoned with the introduction of communicative competence (Cahyono \& Widiati, 2011; Larsen-Freeman, 2001; Richards \& Renandya, 2002).

As this new approach developed, grammatical aspects began to get attention again, due to the importance of the use of the language in an acceptable way (as native speakers of the language use it). Richards and Renandya (2002) state that grammar aspects are too important to be forgotten in learning English, so teachers must take the time to improve learners' grammar skills to help develop their language ability. Some other experts (Debata, 2013; Thornbury, 2002; Ur, 2012) agree that grammar is an important element in the communication process. Mastery of grammar elements contributes to the clarity and effectiveness of communication. Debata (2013) asserts that first language learning at a certain level of mastery requires grammar learning, especially in the context of second/foreign language learning. Larsen-Freeman (2001) warns that the rise in grammar teaching must be balanced by the reconstruction of its teaching; as part of communicative competence, teaching grammar must be directed to the mastery of accurate, meaningful, and accepted aspects of grammar. Ur (2012) suggests that grammar is not limited only to correctness; grammatical forms must also always carry the meaning that is intended to be conveyed in communication.

From the opinions above, all agree that the debate about teaching grammar does not concern whether or not grammar is needed in learning English, but in two important focuses, namely what to teach (content) and how to teach (method) (Cahyono \& Widiati, 2011; Ellis, 2002; Ur, 2012). The first relates to which elements must be taught, based on the level and needs of learners. According to Swan (2002), selection of materials needs to be considered based on comprehensibility and acceptability. In terms of learning expectations, grammar can be taught deductively or inductively. Inductive learning is an approach where learners discover rules from given data/input, whereas deductive learning is an approach of giving explanations of grammar rules, followed by mechanical exercises (Larsen-Freeman, 2001). Farahani (2018) describes the deductive method as a top-down approach, moving from general to specific, by introducing 
grammatical rules or patterns first, followed by a series of exercises. The inductive method, on the other hand, is a bottom-up approach, moving from general to specific by providing contexts or situations. The rules are induced by the students from the contexts. Each approach has advantages and disadvantages, so LarsenFreeman suggests combining the two to get the best results. The debates continue, with both sides presenting evidence to support their positions. Rahman and Rashid (2017) conclude that both approaches have their own strengths and weaknesses. Furthermore, Alenezi (2019) suggests that selecting an approach depends on several factors, such as the purposes of learning, teachers' knowledge, and students' level of English.

In the present research, the selection of the deductive method is based on the three main goals of learning English grammar mentioned above, and students' levels and experiences of learning English. Besides, the deductive method has advantages, including: its superiority in solving grammatical problems quickly and accurately (Mountone, 2004); that it is a more predicable method, because information is presented and sequenced deductively (Younie, cited in Farahani, 2018); that it is straightforward, time-saving, etc. (Widodo, 2006).

\section{Holistic Assessment Approach (AaL, AfL, AoL) in Teaching and Learning}

Assessment plays an important role in learning. It has an impact on students' and teachers' behaviour in teaching and learning activities. The impact can be positive or negative - positive if the assessment activities leads students to learn better, but negative if the assessment activities/processes lead to negative learning (Booth, 2018; Hughes, 2010). This indicates that the teacher must be able to design assessment activities that lead to a positive washback effect. This can be achieved by applying multiple techniques to accommodate multiple functions (achievement, diagnostic, placement/levelling, etc.). Thus, assessment in the teaching and learning process is not just to gauge the success of learning (summative function), but also to improve the learning process (formative function). Aviles and Grayson (2017) emphasise that assessment influences all aspects of school life. It affects students' marks, the curriculum, learning needs, even resources and funding. The effectiveness of the teaching and learning process can be seen through assessment. Thus, assessment must be designed in the form of authentic activities that can enhance high-level thinking (HOTS) and build students' understanding.

In traditional assessment, there is a tendency to emphasise measuring learning outcomes, with less attention paid to the learning process. Summative functions are more dominant than formative ones. The implementation of K-13 in Indonesian education systems in primary and secondary education suggests a reform of assessment that emphasises class assessment, covering assessment of learning (AoL), assessment for learning (AfL), and assessment as learning (AaL) (Depdikbud, 2017). In this research, all those functions of assessment (AfL, AaL, and $\mathrm{AoL}$ ) are labelled as a holistic assessment approach, one that considers multiple purposes of assessment to promote the learning process and results.

However, what needs to be considered in this integration is the proportion of these three areas within this approach. It is a tradition that assessment aims to identify outcomes achieved by learners in the teaching and learning process, so that in the traditional assessment approach, the assessment of learning gets a larger 
proportion than assessment for learning and assessment as learning (Earl, 2003), as illustrated in Figure 1 below.

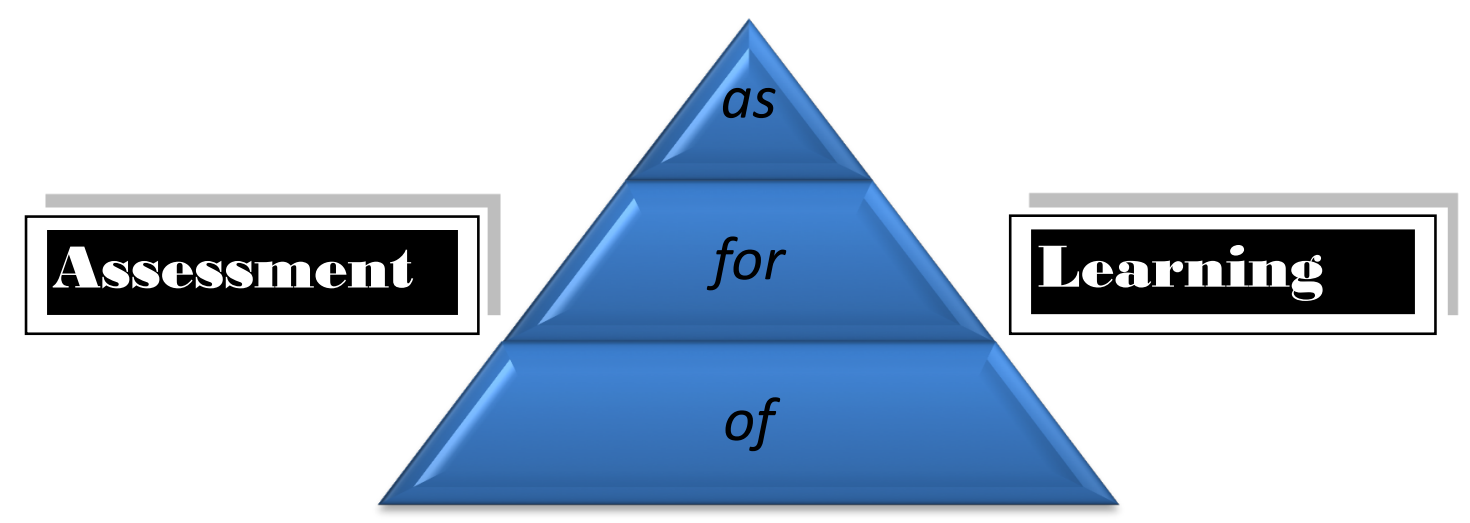

Figure 1. Traditional assessment pyramid (Earl, 2003)

Figure 1 above shows the dominant role of AoL in learning, followed by AfL, with AaL getting the smallest proportion. In the present education paradigm, with the application of various approaches to learning, such as student-centred learning, and authentic assessment, it is expected that the pyramid of assessment will be reconfigured to emphasise formative functions of assessment (AaL and AfL) above the summative assessment function (AoL), as Figure 2 illustrates (Earl, 2003). This means that the process of assessment (formative) is accredited a greater proportion than the result assessment (summative) in improving the quality of learning.

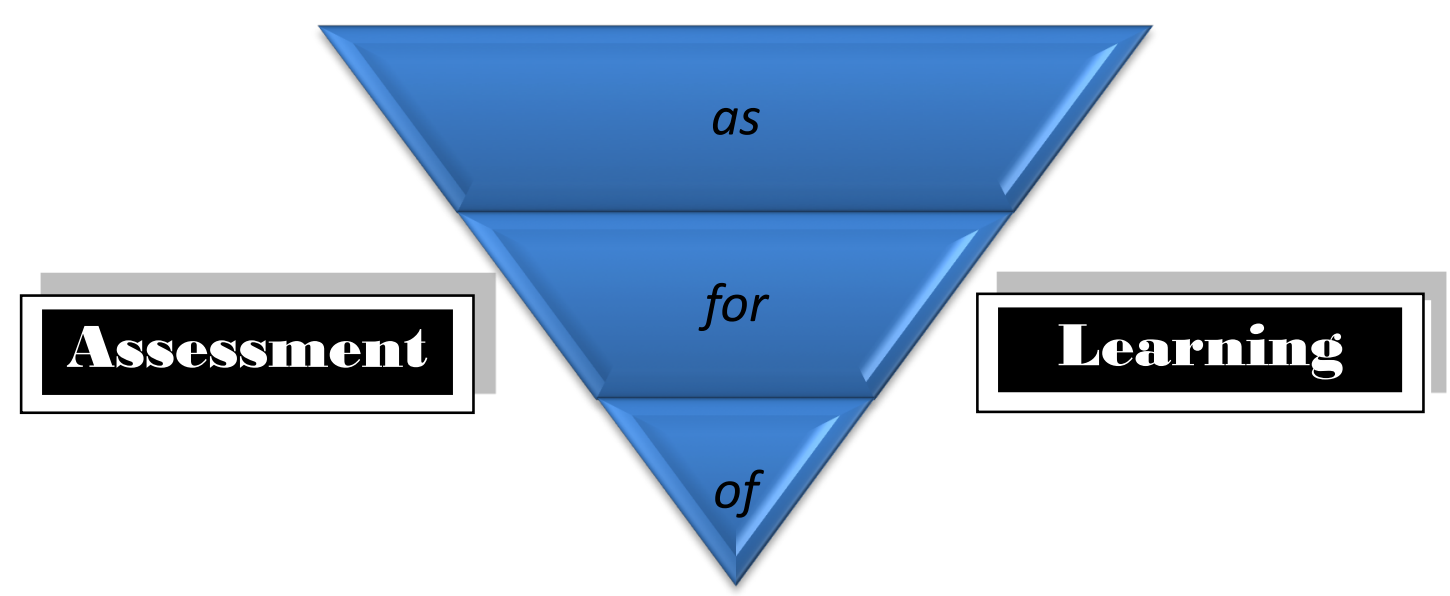

Figure 2. Reconfigured assessment pyramid (Earl, 2003)

Furthermore, the Western and Northern Canadian Protocol for Collaboration in Education (WNCP, 2006) states that these three types of assessment play important roles in the teaching and learning process, to different purposes. However, if the purpose is to impart learning on students, AfL and AaL must be assigned a greater proportion than AoL. It is also suggested by $\mathrm{Ng}$ (2018) that AfL and AaL are capable of supporting students' learning and developing autonomous learning. 
In the context of education in Indonesia, with the application of the 2013 curriculum (K-13) in primary and secondary education (Depdikbud, 2017), and the implementation of SN-DIKTI 44/2015 (Kemenristekdikti, 2015) in higher education, the assessment system has been initiated to balance various assessment functions. The two documents emphasise the importance of process evaluation in learning - realised in AaL and AfL - in supporting outcome assessment (AoL). However, so far there has been no study on the design and implementation of teaching grammar using this approach.

\section{RESEARCH METHOD}

This study employs the research and development approach (R \& D), a research method used to produce certain products, and to test the effectiveness of these products (Sugiyono, 2010). Seels and Richey (in Setyosari, 2013) define development research as a systematic study to design, develop, and evaluate programmes, processes, and learning outcomes that meet the criteria of consistency and internal effectiveness. Development procedures include (1) preliminary study, (2) product development, (3) trials, and (4) dissemination. This study developed English grammar course materials by integrating a deductive method and holistic assessment approach, consisting of AoL, AfL, and AaL. The product was implemented in English grammar lectures. Furthermore, this research was carried out among 72 fourth-semester students from three classes (IVA, IVB, and IVC) in the English education department, FKIP Mataram University.

The data were collected from various sources using the triangulation technique, including tests (using structure and written expression from the TOEFL test), observation of the teaching and learning process, questionnaires to obtain information about students' opinions on the implementation of the teaching and learning process, and documents, comprising the syllabus and teaching materials. In addition, the collected data were analysed quantitatively and qualitatively, depending on the type of data. Data from tests and questionnaires were analysed qualitatively, and data from self-evaluation results, observations, and interviews, were analysed and interpreted qualitatively, following the analysis model of Miles and Huberman (in Sugiyono, 2013). Miles and Huberman suggest that data analysis activities in qualitative research be carried out interactively, and take place continuously. These activities include data reduction, data presentation, and drawing conclusions and verification. (1) Data reduction is the process of selecting, determining focus, simplifying, summarising, and converting raw data so that conclusions are easily drawn and verified. (2) The presentation of data is the translation of data that aims to facilitate and clarify the appearance of data, which should be arranged systematically, interactively, and inventively to help understanding of what has been achieved in this study. (3) Drawing conclusions is an attempt to provide interpretation or meaning from the data presented.

\section{FINDINGS}

\section{Model of integration of deductive method and holistic assessment approach}

The deductive method was realised in the form of systematic and consistent grammatical presentation from each unit, covering: pre-test, materials presentation 
followed by exercises to support the concepts, self-assessment and reflection on learning, and post-test. The pre-test and post-test elements were provided in two formats: pre-test at the beginning of the semester, and post-test at the end of the semester, using TOEFL - structure and written expression (SWE), and pre-test and post-test for each unit using various formats of assessment. Holistic assessment was integrated with the materials. The results of the integration are presented in Table 1 below.

Table 1. Model of integration of deductive method and holistic assessment approach

\begin{tabular}{|c|c|c|}
\hline STAGES & ACTIVITIES & HOLISTIC ASSESSMENT \\
\hline Stage 1 & $\begin{array}{l}\text { Presentation of Learning Objectives \& } \\
\text { Pre-test }\end{array}$ & Assessment as Learning (AaL) \\
\hline \multirow[t]{9}{*}{ Stag e 2} & $\begin{array}{l}\text { Deductive method (Presentation, Practice } \\
\& \text { Production) }\end{array}$ & \\
\hline & 1. Presentation of Subtopic 1 & \\
\hline & 2. Practice 1 & Assessment for Learning (AfL) \\
\hline & 3. Presentation of Subtopic 2 & \\
\hline & 4. Practice 2 & Assessment for Learning (AfL) \\
\hline & 5. Presentation of Subtopic 3 & \\
\hline & 6. Practice 3 & Assessment for Learning (AfL) \\
\hline & 7. Presentation of Subtopic $n$ & \\
\hline & 8. Practice $n$ & Assessment for Learning (AfL) \\
\hline Stage 3 & Self-assessment \& Learning Reflection & Assessment as Learning (AaL) \\
\hline Stage 4 & Post-test & Assessment of Learning (AoL) \\
\hline
\end{tabular}

As seen in Table 1 above, the teaching and learning processes were dominated by the application of formative assessment (AfL and AaL). The material presentation was carried out step-by-step on every subtopic, followed by various kinds of exercises (practices) for strengthening the concepts (AfL). After completing all subtopics in each respective unit, students were asked to self-assess and reflect on their own learning. Self-assessment was carried out by reproducing achievement indicators presented previously, at the beginning of each unit. Reflection on learning was carried out by asking them to summarise using a mindmapping technique (AaL). Finally, to check students' understanding, each unit ends up with post-test assessment (AoL) in various forms - sentence combinations, short answers, and objective tests.

All six units in this course were designed systematically following these patterns. As seen in the design, EG course materials were presented deductively by providing explanations of each sub-topic, followed by mechanical exercises as practice activities. The roles of exercises and activities in each unit are directed towards increased processes (formative purposes) by employing AfL and AaL rather than increased products (summative purposes), as represented by AoL.

The teaching and learning process in each unit was conducted following these steps: (1) before going to class, students were required to take a pre-test to check their entry behaviour towards the respective unit, and they were asked to look at learning objectives and achievement indicators presented at the beginning of each unit in order to give them the direction on the unit. These activities were intended to achieve AaL and AfL; (2) materials presentation was carried out step-by-step, by sub-topic, followed by practice and production in this area. The practice and production was intended to promote learning (AfL); (3) having completed all 
sub-topics in each unit, students were assigned a self-assessment activity, marking the achievement indicator list with ticks (v), crosses (x), or question marks (?), depending on their situation. Further actions also depended on their situations. The activity was then extended to summarising the unit using a mind-mapping technique (AaL); (4) to check the overall activities, students were assigned a post-test for each unit (AoL).

\section{Students' learning achievement}

From testing before and after the teaching and learning process, using Section 2 of the TOEFL test - structure and written expressions (SWE), the following results emerged:

Table 2. The results of pre-tests and post-tests on SWE TOEFL $(N=72)$

\begin{tabular}{|c|c|c|c|c|c|c|}
\hline \multirow[t]{2}{*}{ NO } & \multirow{2}{*}{$\begin{array}{l}\text { SCORE } \\
\text { RANGE }\end{array}$} & \multirow{2}{*}{ CATEGORY } & \multicolumn{2}{|c|}{ PRE-TEST } & \multicolumn{2}{|c|}{ POST-TEST } \\
\hline & & & $\mathrm{f}$ & $\%$ & $f$ & $\%$ \\
\hline 1 & $<308$ & False beginner: non-user & 9 & 12.5 & 0 & 0.00 \\
\hline 2 & $308-346$ & Basic: minimal user & 7 & 9.72 & 2 & 2.78 \\
\hline 3 & $347-385$ & Elementary: very limited user & 23 & 31.94 & 10 & 13.89 \\
\hline 4 & $386-424$ & Lower-intermediate: limited user & 14 & 19.44 & 16 & 22.22 \\
\hline 5 & $425-463$ & Intermediate: adequate user & 8 & 11.11 & 14 & 19.44 \\
\hline 6 & $464-502$ & $\begin{array}{l}\text { Post intermediate: independent } \\
\text { user }\end{array}$ & 7 & 9.72 & 17 & 23.61 \\
\hline 7 & $503-541$ & Pre-advanced: competent user & 3 & 4.17 & 6 & 8.33 \\
\hline 8 & $542-580$ & Advanced: proficient user & 1 & 1.39 & 4 & 5.56 \\
\hline 9 & $581-620$ & $\begin{array}{l}\text { Professional user: highly proficient } \\
\text { user }\end{array}$ & 0 & 0.00 & 3 & 4.17 \\
\hline \multirow[t]{4}{*}{10} & $>620$ & Near-native speaker: expert user & 0 & 0.00 & 0 & 0.00 \\
\hline & & TOTAL & 72 & 100.00 & 72 & 100.00 \\
\hline & & TOEFL mean score & \multicolumn{2}{|c|}{388.84} & \multicolumn{2}{|c|}{452.08} \\
\hline & & Score range & \multicolumn{2}{|c|}{$260-580$} & \multicolumn{2}{|c|}{$330-610$} \\
\hline
\end{tabular}

Table 2 above shows the achievement of EED UNRAM students in pre-tests and post-tests using SWE TOEFL. It shows a very wide range (320 points) from 260 to 580, with an average score of 388.84 from the maximum score of 680 . Most students (53 or 75\%) are categorised as below the limited users (lower intermediate), with scores below 424; 15 students (20.8\%) are rated as adequate and independent users; and only four are categorised as competent and proficient users. This result concludes that students' ability in English grammar is still low (limited users), this after completing a four-credit course in contemporary English grammar and some other skill courses (speaking, listening, reading, and writing) at elementary levels.

After implementing an integration of the deductive method and holistic assessment approach for 14 meetings (@100 minutes) for one semester (for a twocredit course), the results of post-tests showed an increase of 63.24 points, with an average of 452.08 and a range score of 280 points, from 330 to 610. Although in general the results show an improvement, there are still several students (28 or $38.8 \%$ ) categorised as limited users with a score below 424. A steep increase occurs 
in the categories of adequate and independent users from 15 (20.8\%) students on the pre-test to $31(43.1 \%)$ students on the post-test, and from four $(5.5 \%)$ to 10 $(13.8 \%)$ on the categories of competent and proficient users. Besides, three (4.2\%) students reached highly proficient user level with range scores from 581-620.

To put it in more simply, the data in Table 2 above can be translated into the following figure to show the increase from pre-test to post-test:

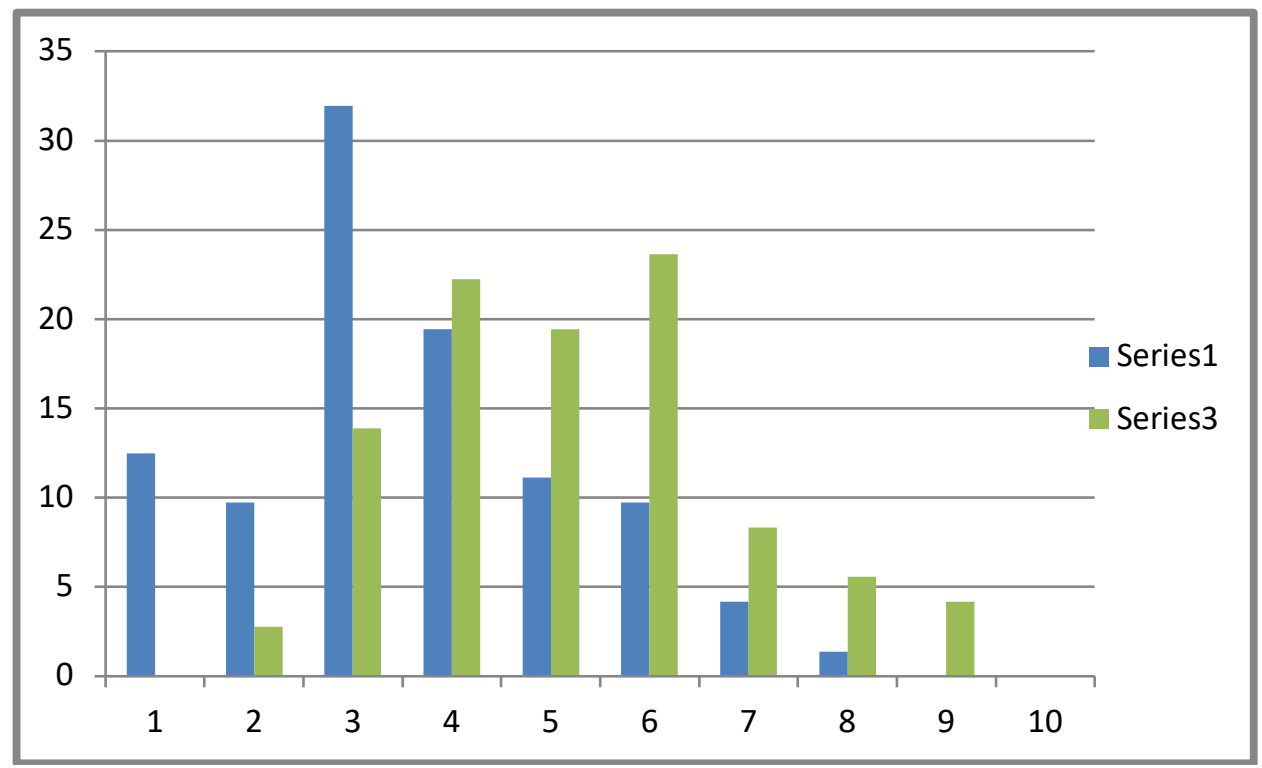

Figure 3. Results of pre-test and post-test SWE TOEFL English students

$$
(N=72)
$$

To test the significance of the results of the pre-test and post-test on SWE TWOFL, the data were then analysed using a paired-sample $t$ test:

Table 3. Paired samples test

\begin{tabular}{|c|c|c|c|c|c|c|c|c|c|}
\hline & \multicolumn{5}{|c|}{ Paired Differences } & \multirow[b]{3}{*}{$\mathrm{t}$} & \multirow[b]{3}{*}{$\mathrm{df}$} & \multirow{3}{*}{$\begin{array}{l}\text { Sig. (2- } \\
\text { tailed) }\end{array}$} \\
\hline & & \multirow[b]{2}{*}{ Mean } & \multirow{2}{*}{$\begin{array}{c}\text { Std. } \\
\text { Deviatio } \\
\text { n }\end{array}$} & \multirow{2}{*}{$\begin{array}{l}\text { Std. } \\
\text { Error } \\
\text { Mean }\end{array}$} & \multicolumn{2}{|c|}{$\begin{array}{l}95 \% \text { Confidence } \\
\text { Interval of the } \\
\text { Difference }\end{array}$} & & & \\
\hline & & & & & Lower & Upper & & & \\
\hline $\begin{array}{l}\text { Pair } \\
1\end{array}$ & $\begin{array}{l}\text { Pre- } \\
\text { test to } \\
\text { Post-te } \\
\text { st }\end{array}$ & 63.611 & 80.234 & 9.456 & -82.465 & -44.757 & -6.727 & 71 & .000 \\
\hline
\end{tabular}

The results in the output table above show that the sig. (2-tailed) is 0.000 $<0.05$, meaning that the relationship between the two variables (pre-test and posttest) is significant (Santoso, 2014). It indicates that the integration of the deductive method and holistic assessment have a significant relationship in teaching English grammar at EED UNRAM. 


\section{Student responses to planning and implementation of teaching EG}

The students' responses on the planning and implementation of English grammar classes using the deductive method and the holistic assessment approach were collected through an online questionnaire using Google Forms and interview. Of 72 questionnaires distributed, 54 were returned, and results are summarised below:

\section{Student response to the English grammar module}

Students responded positively to the modules used in teaching English grammar in terms of material coverage, level of difficulty, suitability for needs, and completeness of exercises to support the implementation of the holistic assessment approach (AfL, AaL, and AoL). In detail, the results of the questionnaire can be seen in the following presentation:

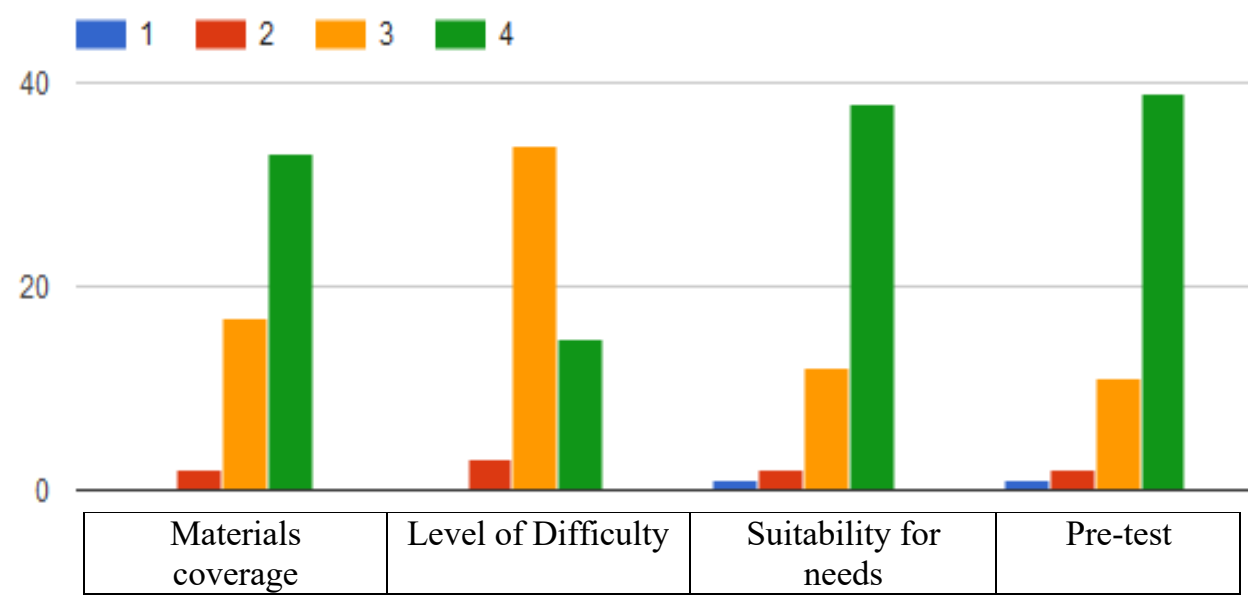

Figure 4. Students' response to the module

In terms of materials coverage, $96.26 \%$ of students responded that the module used was very appropriate and matched the intended goals of this subject. Students also positively assessed the balance achieved between the level of difficulty of the material and the ability of students $(96.26 \%$ ); only $3.8 \%$ (two people) stated that the material was inappropriately pitched. As to the suitability of EG materials for their needs to be teachers and language users, 94.33\% stated that it was appropriate or very appropriate.

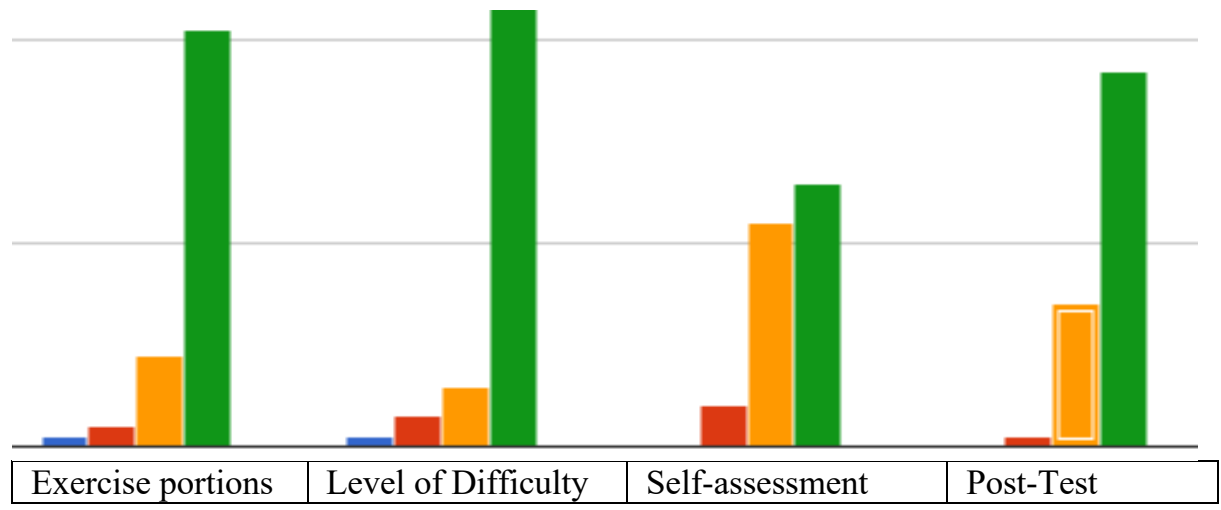

Figure 5. Students' response to the module 
Regarding the exercises to support the implementation of the holistic assessment approach (AfL, AaL, and AoL), students commented that the module was equipped with types of assessments that would strengthen their learning. Assessment for learning (AfL) was addressed in the form of various exercises on each sub-topic, and assessment as learning (AaL) was addressed through selfevaluation and reflection on learning. Over $90 \%$ of students found that the modules provided enough training content to improve learning (AfL), with a level of difficulty that suits their abilities, and provides an opportunity for students to evaluate themselves and self-reflect (AaL).

\section{Students' response to the teaching and learning process}

The implementation of the teaching and learning process also received positive responses from students in terms of clarity and systematic steps of presentation, the role of exercises in improving learning (AfL), the role of group and pair work, the role of self-evaluation and reflection on learning $(\mathrm{AaL})$.

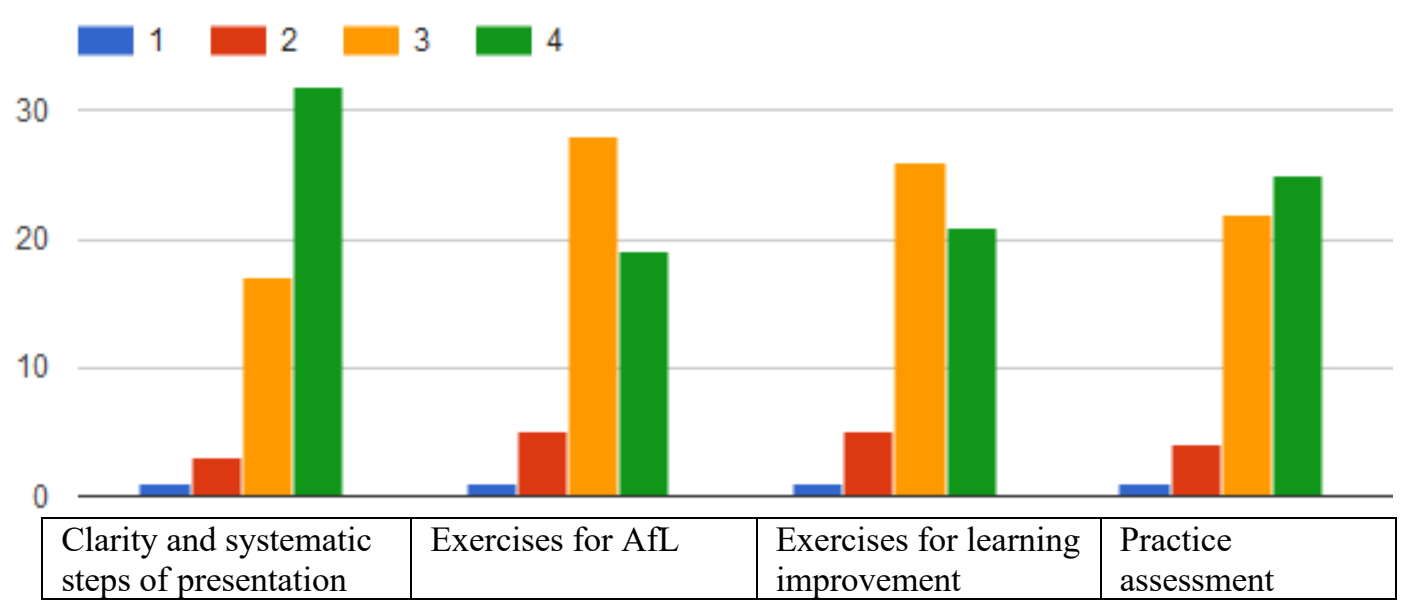

Figure 6. Students' responses to the implementation

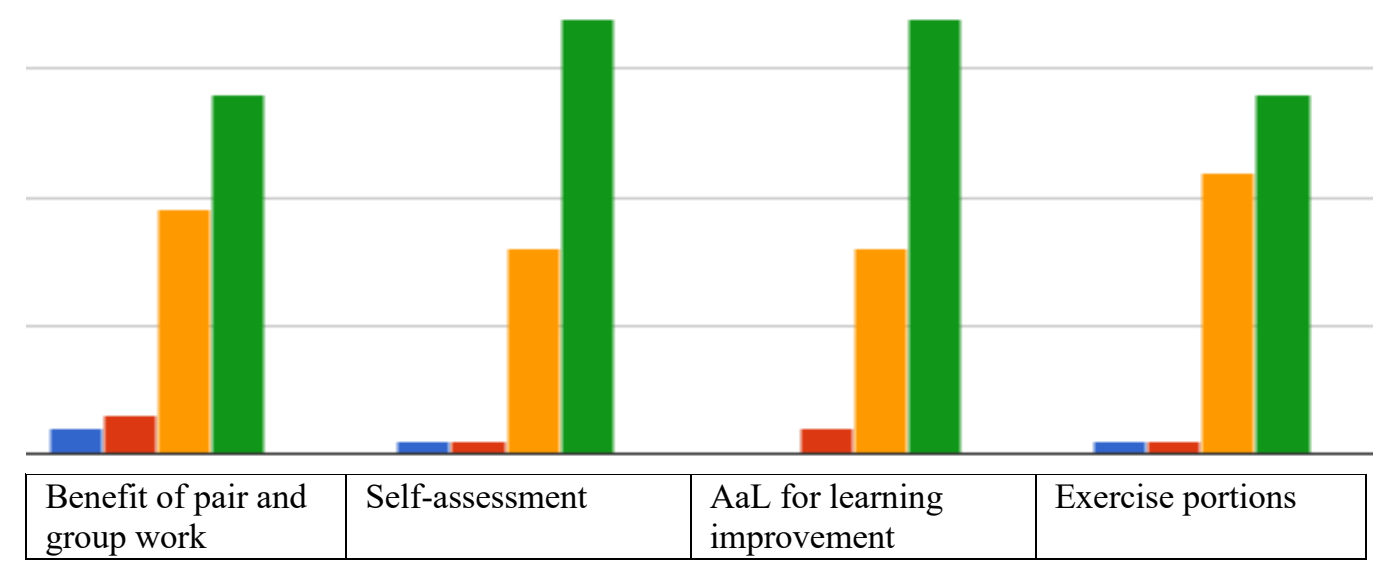

Figure 7. Students' responses to the implementation 


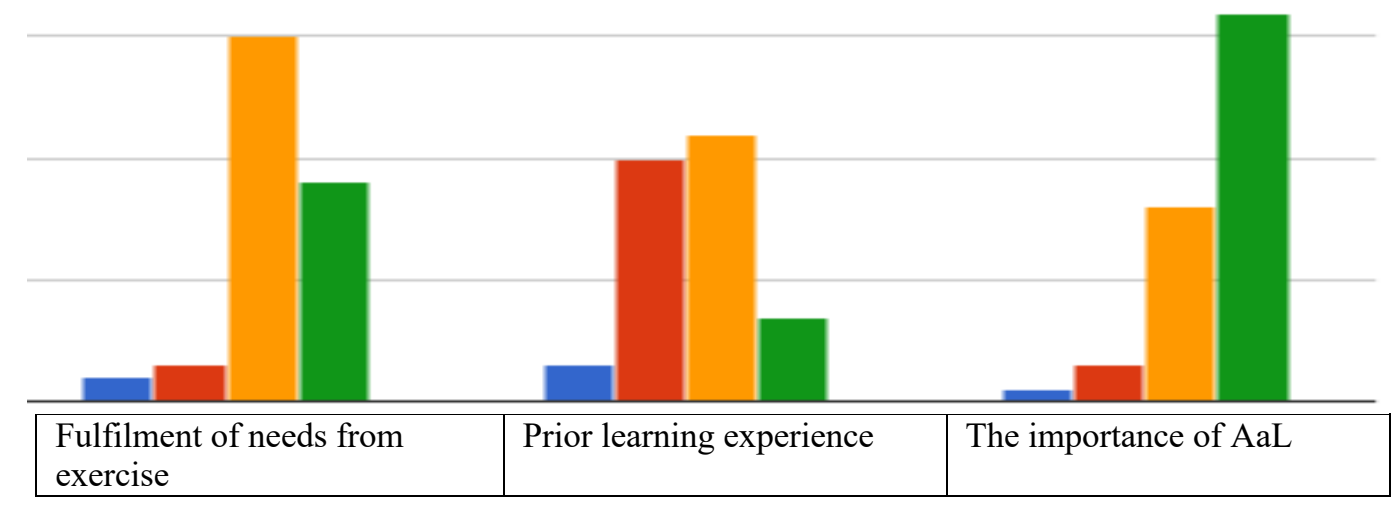

Figure 8. Students' responses to the implementation

The figure above shows the students' response to the clarity and organisation of the materials. Of the 52 student respondents, $92.45 \%$ stated that the material was presented in a straightforward and clear manner; only $7.55 \%$ stated that it was unclear and not well organised. In addition, most students (88.67\%) also responded positively to the role of exercises in improving assessment for learning and self-evaluation, and in reflecting on the capability of learning to impart further learning. Most respondents admitted that they did not get used to carrying out selfassessment or reflecting on learning activities, but they suggested these practices should continue.

\section{DISCUSSION}

The results of this study show that the integration of the deductive method and holistic assessment in teaching English grammar is significant. As mentioned above, the purposes of teaching English grammar for students of EED are threefold: to improve accuracy in communication, to prepare them to be English teachers, and to achieve graduation (they are required to achieve a score of at least 500 on the TOEFL test) (Sujana et al., 2018). To achieve such targets, it is not enough for students to have implicit or procedural knowledge; they are also required to have explicit or declarative knowledge of English grammar through an active and conscious learning process (Alenezi, 2019). This opinion is in line with Scheffer and Cinciata's (2011) recommendation stating the importance of investing time in teaching grammar explicitly. Explicit instructions are commonly needed by students struggling with acquiring a second or foreign language (Alenezi, 2019) and by those who are working on a more advanced use of English (Ellis, 2006).

The teaching of English grammar in the present study was designed to meet the application of the deductive method by providing a systematic presentation for each unit. This started with pre-test, through learning objectives, materials presentation and exercises for each sub-unit, to self-assessment and reflection on learning, to post-test. The adoption of the deductive method of teaching was in line with the advantages of this method, such as its superiority in solving grammatical problems quickly and accurately (Mountone, 2004; Althaqafi, 2018), and its capacity to get straight to the point, so as to save time (Widodo, 2006; Rahman \& Rashid, 2017).

\section{Indonesian TESOL Journal}


However, learning English grammar is directed not only towards achieving an understanding of concepts, but also engenders an ability in the learner to use grammatical elements in communication (spoken and written). The second goal is achieved by integrating the deductive method with the application of holistic assessment, comprising formative assessment (AaL, AfL) and summative assessment (AoL); this follows Earl's (2003) suggestion that assessment should be directed not merely at students' achievement at the end of the T-L process, but should be directed more towards improving the learning process. Therefore, formative assessment (AfL and $\mathrm{AaL}$ ) was assigned a greater proportion of the T-L process than was summative assessment (AoL). AfL was realised in various exercises given after each section, to provide practice in order to strengthen students' grasp of concepts. Through this series of exercises, students could monitor their progress (Clark, 2012).

The AaL was conducted in the form of self-assessment and reflection on learning. Self-assessment was carried out by asking participants to assess their achievement on each indicator established at the beginning of each unit. Students' self-assessment was followed up with written mind-mapping. Using these activities, the students internalised and reflected on their learning to check what they had achieved and what they had missed. This reinforces Dann's (2014) opinion that, through AaL activities, students can self-regulate and make decisions on their own learning. Furthermore, applying formative assessment in teaching English grammar for this study is in line with opinions that formative assessment can support learning, improve outcomes, and enhance self-actualisation (Clark, 2012). This application also matches assessment principles for higher education institutions stated in SN-DIKTI 44/2015 regarding the National Standards of Education (Kemenristekdikti, 2015). One of the principles is educative, meaning that the assessment should be capable of improving students' learning (formative functions), and not just fulfil summative purposes (AoL).

The summative assessment was given in the form of a post-test for every unit, final tests, and a test on the SWE section of the TOEFL test in order to check their achievements. As suggested above, the proportion of AoL is less than that of AfL and AaL.

The findings in the present research contribute to recognition of the importance of teaching English grammar explicitly when the purposes of the course are to impart grammar knowledge in preparation for English teaching. Students in this field need declarative knowledge of EG, and must face the structure and written expression section of the TOEFL test, which requires a detailed understanding of grammar. Deductive teaching can be accelerated by the various functions of assessment - assessment as learning, assessment for learning, and assessment of learning. This study at the same time suggests that it is necessary to differentiate between the teaching of grammar as a course or subject, and advanced use of language with the teaching of grammar as a language element to support communication. 


\section{CONCLUSION}

This study has investigated how the deductive method was integrated with holistic assessment in order to promote the teaching and learning process and product within the teaching of English grammar at EED University of Mataram, Lombok, Indonesia. The materials design was made explicit by providing a stepby-step grammar presentation for each unit, supported by holistic assessment to support deductive learning. The holistic assessment was designed to achieve multipurpose assessment; that is, for formative purposes (assessment as learning, assessment for learning) and summative functions (assessment of learning), with formative assessment comprising the greater portion. Furthermore, the integration of the deductive method with holistic assessment makes a significant contribution to teaching English grammar for students of English education. Applying the deductive method is appropriate to the situation in which the purposes of learning EG are preparing students to be English teachers, providing them with declarative knowledge of EG, and helping them to meet graduation requirements (500 on TOEFL), all of which require accuracy in using grammar. Then, students responded positively to both the model used in materials design, and to the teaching and learning process that applied the deductive method and holistic assessment approach to all aspects being investigated (clarity, completeness, fulfilment of needs, adequacy of practice, and self-assessment). In addition, the practical implication of this research is that teachers of grammar in English education need to consider applying holistic assessment in both design and implementation. It is necessary, then, to reconstruct grammar classes to provide students with comprehensive materials and to facilitate their learning.

Although integrating the deductive method with holistic assessment improved students' achievements, several students performed below expectation. The number of students achieving the required scores for graduation, for example, is still low. The English grammar team at EED UNRAM should work hand-in-hand to improve the quality of process and product. Then, the problem faced by students in learning EG at an advanced level lies in students' readiness to internalise materials due to their low entry behaviour. That makes them unable to master the materials properly. With the density of materials in all EG courses at EED, there must be alternative solutions to accelerate the acquisition of English grammar needed by EED students to meet the mentioned goals. The use of blended learning or a hybrid approach could be a solution in this digital era. Finally, further research needs to be conducted to find various alternative solutions in teaching and learning English grammar from different perspectives.

\section{ACKNOWLEDGMENTS}

Researchers would like to extend their gratitude to:

1. University of Mataram, Lombok, for funding this research through the PNBP UNRAM budget.

2. Both reviewers, who have given valuable and constructive feedback for improvements to this article.

\section{Indonesian TESOL Journal}




\section{REFERENCES}

Alenezi, S. M. (2019). Exploring explicit and Implicit grammar teaching. International Journal of Applied Linguistics and English Literature, 8(1), 104-106.

Althaqafi, A. S. (2018). A critical review of grammar teaching methodologies in the Saudi contexts. English Language Teaching, 11(11), 65-73.

Arifuddin, \& Sujana, I. M. (2004, February). Kecakapan berbahasa Inggris mahasiswa senior ps pendidikan bahasa inggris LPTK di Nusa Tenggara Barat. Jurnal Penelitian Universitas Mataram .

Aviles, N., \& Grayson, K. (2017, August). Backward planning - how assessment impacts teaching and learning. IDRA Newsletter .

Booth, D. K. (2018). The sociocultural activity of high stakesstandardized language tests. Switzerland: Springer International Publising.

Cahyono, B. Y., \& Widiati, U. (2011). The teaching of English as a foreign language in Indonesia. Malang: State University of Malang Press.

Celce-Murcia, M. (1992). Formal grammar instruction. TESOL Quaterly , 36 (2), 406-409.

Clark, I. (2012). Formative assessment: assessment is for self-regulated learning. Educational Psychology Review, June 2012, DOI 10.1007/s10648-0119191-6.

Debata, P. K. (2013). The Importance of Grammar in English Language Teaching: A Reassessment. Language in India , 13 (5), 482-496.

Depdikbud. (2017). Materi Bimbingan teknis Fasilitator dan Instruktur Kurikulum 2013 Tahun 2017. Jakarta: Kementerian Pendidikan dan Kebudayaan.

Earl, L. M. (2003). Assessment as Learning: Using Classroom Assessment to Maximize Student Learning. Thousand Oaks, CA: Corwin Press.

Ellis, R. (1995). Interpretation tasks for grammar teaching. TESOL Quarterly, 29(1), 87-106

Ellis, R. (2002). Grammar teaching - practice or conciuos-raising? In J. C. Richards, \& W. A. Renandya, Methodology in language teaching: an anthology of current practice (pp. 167-174). Cambridge: Cambridge University Press.

Ellis, R. (2006). Current issues in the teaching of grammar: an SLA perspective. TESOL Quarterly, 40(1), 83-107.

Farahani, M. V. (2018) An investigation into inductive and deductive methods in teaching grammar to German EFL learners: a comparative study. Global Journal of Foreign Language Teaching, 9(2), 76-91.

Hinkel, E., \& Fotos, S. (2002). From theory to practice: a teacher's view. In E. Hinkel, \& S. Fotos, New perspective on grammar teaching in second language classroom (pp. 1-15). New Jersey: Lawrence Erlbaum Associates, Inc. 
Huang, Z. W. (2005). Grammar teaching as product or as process? Sino-US English Teaching, 2(11), 27-31.

Hughes, A. (2010). Testing for language teachers. Cambridge: Cambridge University Press.

Iswanto, A. (2016). The Correlation between the Scores of English Grammar Couses and the Scores of SWE on TOEFL of EED Students UNRAM. (Thesis) Mataram: Faculty of Teacher Training and Education, UNRAM.

Kemenristekdikti. (2015). Permenristekdikti No. 44/2015 tentang Standar Nasional Pendidikan Tinggi (SN-DIKTI). Jakarta: Kementerian Riset, Teknologi, dan Pendidikan Tinggi.

Krashen, S. (1999). Seeking a role for grammar: review of some recent studies. Foreign Language Annals , 32 (2), 245-254.

Krashen, S. (1985). The input hypothesis. Harlow: Longman

Larsen-Freeman, D. (2001). Teaching grammar. In M. Celce-Murcia (Ed.), Teaching English as a Second Language (3rd edition ed., pp. 251 -266). United States: Heinle \& Heinle.

Leachtenauer, J. (2004). Teaching gramar through grammar consciousness-raising tasks. Journal of Inquiry and Research , 80, 1-11.

Mountone, P. (2004) How to use example effectively: deductive vs inductive approaches. Santa Barbara, CA: University of California.

Ng, C. W. (2018). Assessment for/as learning in Hong Kong English language classroom: A review. International Journal of Research in English Education (IJREE), 3:3, 1-12.

Rahman, A. M. A., \& Rashid, R. A. (2017). Explicit and implicit grammar instructions in higher learning institutions. English Language Teaching, 10(10), 92-101.

Richards, J. C., \& Renandya, W. A. (2002). Methodology in language teaching: an athology of current practice. Cambridge: Cambridge University Press.

Santoso, S. (2014). SPSS 22 from essential to expert skills. Jakarta: PT Elex Media Komfutindo

Scheffer, P., \& Cinciata, M. (2011). Explicit grammar rules and L2 acquisition, ELT Journal, vol. 6/1, 13-23.

Septiansyah, A. (2017). An analysis of problems faced by senior students in SWE section of TOEFL. (Thesis). Mataram: the University of Mataram.

Setyosari, P. (2013). Metode penelitian pendidikan dan pengembangan. Jakarta: Prenadamedia Group.

Sugiyono. (2013). Metode penelitian kuantitatif, kualitatif, dan $R \& D$. Bandung: Alfabeta.

Sujana, I. M., Udin, U., Susanti, N. W. M., \& Arifuddin, A. (2018). Optimizing process and product in teaching English grammar using AaL, AfL, and AoL 
at English Education, University of Mataram. Research report. Mataram: LPPM.

Swan, M. (2002). Seven bad reason for teaching grammar - and two good ones. In J. C. Richards, \& W. A. Renandya, Methodology in language teaching: an anthology of current practices (pp. 148-166). Cambridge: Cambridge University Press.

Thornbury, S. (2002) How to teach grammar. Essex: Pearson Education.

Ur, P. (2012). A course in english language learning (2nd ed.). Cambridge: Cambridge University Press.

Widodo, H. P. (2006) Approaches and procedures for teaching grammar. English Teaching: Practice and Critique, 5(1), 122-141.

WNCP. (2006). Rethinking classroom assessment with purpose in mind. Canada: WNCP . 